
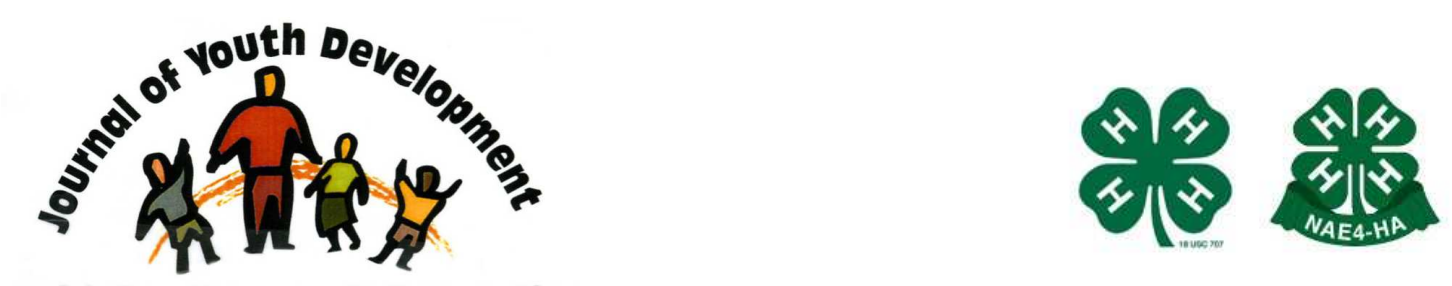

Bridging Research \& Practice

\title{
Reading Makes Cents Resource Review
}

\author{
Lacie Ashby \\ University of Maryland Extension \\ Allegany County \\ Cumberland, MD \\ lashby@umd.edu \\ Kathy Gordon \\ University of Maryland Extension \\ Carroll County \\ Westminster, MD \\ kgordon1@umd.edu \\ Shante Stokes \\ University of Maryland Extension \\ Prince George's County \\ Clinton, MD \\ sstokes@umd.edu
}




\title{
JOURNAL OF YOUTH DEVELOPMENT \\ bridging research and practice

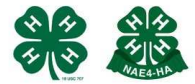

Bridging Research \& Practice

Volume 6, Number 4, Winter 2011

Article 110604RR001

\section{Reading Makes Cents \\ Resource Review}

Lacie Ashby, Kathy Gordon and Shante Stokes

\begin{abstract}
In today's economy, it is more crucial than ever to focus our educational efforts on increasing financial literacy. Many young people are unskilled in managing their personal finances, yet this critical life skill will greatly affect their future economic well-being. Reading Makes Cents, developed by Penn State University, is an excellent resource to address this need. A reviewed and recommended curriculum by National 4- $\mathrm{H}$, this complete, easy to use curriculum targets youth in grades 3-5 with a combination of financial literacy and reading. The curriculum explores basic money concepts such as spending, saving, and sharing money. Lessons incorporate hands-on activities and children's literature to reinforce lesson objectives. With evaluation questions and family activities included, Reading Makes Cents is a perfect guide for educators to easily pick up and teach.
\end{abstract}

\section{Introduction}

Created by Penn State University (2008), Reading Makes Cents presents 53 lessons among seven sections in a complete curriculum to teach financial literacy and reading. Targeting youth in grades 3-5, this National 4-H reviewed and recommended curriculum utilizes children's literature to teach and support basic money concepts.

\section{Curriculum}

As a complete package, the curriculum includes easy to understand sections and lessons, each with a fun activity. The curriculum topics are:

- History of Money

- Managing

- Earning

- Spending

- Saving

- Sharing

- Borrowing and Lending

Each lesson includes skills to be learned, recommended literature, introductory comments to the highlighted book, discussion related to the concepts addressed in the book, and an activity 
including a list of needed materials. Lessons can build on one another, or they can be used as stand-alone single sessions, making this curriculum ideal for in-school instruction, afterschool programs, or camp settings.

Creative additions to the curriculum consist of literature resource lists for educators to use and/or substitute in lessons, money quotes, money jokes to be used as needed while instructing, and even a resource list of songs having a money theme. Also included are 16 pages of detailed family time activities, in English and Spanish, for youth to do at home. Educators also benefit from evaluation success indicators, parent communication sheets, and family time activity surveys.

Lessons are written with step by step guidelines and discussion scripts so that an educator can feel confident using the curriculum without prior training or financial education experience. The wide range of lessons allows educators to choose which lesson will work best for their group, based on educational level, facility space, and available materials.

During the past year, University of Maryland Extension's (UME) Money Smart Impact Team pilot tested Reading Makes Cents in three geographically and demographically diverse counties. Based on the pilot evaluation data, the curriculum achieved the intended positive outcomes. Participating pilot sites gave positive feedback on the lessons and activities. A day camp supervisor commented, "It takes a really good program to make kids want to come do this and skip gym and the pool." This speaks to the fact that youth are choosing to participate in Reading Makes Cents, over other recreational alternatives.

In addition, instructors felt the curriculum was easy to use, and said the youth responded positively to the activities and literature. The pilot also demonstrated that the program can be easily replicated in many geographical areas and settings.

One limitation noted by the pilot team is the inability to measure long term behavior change. Reading Makes Cents has adequate evaluation of knowledge gained, however it does not measure behavior change, a challenge among many youth curricula. In this particular case, we can only hope that the youth will retain the information long enough to utilize it in their adult lives to improve their financial future.

The curriculum has been reviewed to meet the National Standards in K-12 Personal Finance Education. In addition, the UME pilot team has also closely compared Reading Makes Cents to the Maryland State Curriculum for Personal Financial Literacy Education, finding the majority of lessons match one or more indicators required by Maryland State Board of Education regulations.

Resources such as free downloads including lessons, money trivia, and links to other relevant websites can be found at http://www.4-h.org/resource-library/curriculum/4-h-reading-makescents/.These supplemental tools found on the website, contribute to lesson reinforcement and allows Educators to sample the curriculum prior to purchasing it.

\section{Reference}

Penn State University. (2008). Reading Makes Cents. National 4-H Council.

(C) Copyright of Journal of Youth Development $\sim$ Bridging Research and Practice. Content may not be copied or emailed to multiple sites or posted to a listserv without copyright holder's express written permission. However, users may print, download or email articles for individual use. 